\title{
Aflatoxin M1 in Milk and some Dairy Products: Level, Effect of Manufature and Public Health Concerns
}

\author{
Asmaa B.M.B. Tahoun ${ }^{*}$, Mona M. Ahmed ${ }^{2}$, Rasha M.M. Abou Elez ${ }^{3}$ and Samah S. AbdEllatif ${ }^{1}$ \\ ${ }^{1}$ Food Control Department, Faculty of Veterinary Medicine, Zagazig Univeristy, 44511, \\ Egypt \\ ${ }^{2}$ Forensic Medicine and Toxicology Department, Faculty of Veterinary Medicine, \\ ZagazigUniveristy, 44511, Egypt \\ ${ }^{3}$ Zoonoses Department, Zagazig University, Faculty of Veterinary Medicine, 44511, Egypt
}

Article History: Received: 12/5/2017 Received in revised form: 1/6/2017 Accepted: 15/6/2017

\begin{abstract}
Aflatoxins (AFs) are toxic and carcinogenic metabolites produced by a variety of fungi. Aflatoxin M1 (AFM1) is the major carcinogenic type frequently found in milk and dairy products, thus posing a significant impact on human health. The current study was undertaken to examine milk and some dairy products for contamination with AFM1 in local markets, Sharkia Governorate, Egypt, as well as the effect of manufacture. A total of 75 samples (15, each) of raw milk, pasteurized milk, yoghurt, processed cheese and Domiati cheese were randomly collected. AFM1 was detected in $27(36 \%)$ out of the examined samples in which the level of AFM1 exceeded the limits $(0 \mathrm{ng} / \mathrm{L}, \mathrm{kg})$ allowed by Egyptian regulation but only $6(8 \%)$ samples exceeded the limits $(50 \mathrm{ng} / \mathrm{L}, \mathrm{kg})$ allowed by European Commission regulation. Levels of AFM1 contamination in the examined milk and dairy products with mean values of $35.68 \pm 10.90$, $45.83 \pm 7.80,7.57 \pm 1.92,24.53 \pm 3.91$ and $42 \pm 4.93 \mathrm{ng} / \mathrm{L}, \mathrm{kg}$ in raw milk, pasteurized milk, yoghurt, processed cheese and Domiati cheese, respectively, were detected. The level of AFM1 decreased after yoghurt manufactur, while, cheese manufacture showed concentration of AFM1 in curd than those in cheese milk. During refrigeration storage of yoghurt, the mean AFM1 toxin decreased after one, two, three, seven days, respectively, then nearly similar level from seven days to fourteen days of storage. In conclusion, widespread presence of AFM1 in raw milk and some dairy products were considered to be possible hazards for public health especially children therefore, continuous monitoring of AFM1 level in commonly marketed raw milk and dairy products in Sharkia markets should be regularly done. Manufacture and storage had little effect on AFM1 content in milk and dairy products, therefore, new or modern technologies for detoxification of milk should be further studied.
\end{abstract}

Keywords: Milk, Dairy products, AFM1, Yoghurt manufacture, Cheese manufacture, Mycotoxins.

\section{Introduction}

Milk and dairy products are principal components in human diet that may be the way for entrance of mycotoxins into the human body posing risk for consumers, inparticular, infants and young children $[1,2]$.

Mycotoxins, principaly produced by filamentous fungi, are naturally occurring secondary metabolites [3]. They constitute a major problem for food industries due to their effect on productivity, welfare and health of dairy animals, as well as, they impair food safety for humans and animals [4]. Global concerns about mycotoxins have been evoked due to their association with certain animal and human disorders such as acute toxicity and sometimes they are linked with certain types of cancer [5].

Aflatoxins (AFs) produced by Aspergillus flavus, Aspergillus parasiticus and rarely by Aspergillus nomius are the most carcinogenic and toxic type of mycotoxins. They can contaminate cattle feed, fruits, vegetables, different types of food and cereals [6].

Twenty AFs including AFB1, AFB2, AFG1 and AFG2 belong to a larger group of toxic compounds named di-furanocoumarins, are the 
most concerned types that naturally contaminate food [7]. Of them, AFB1 is the most toxic and carcinogenic and classified according to the International Agency for Research on Cancer (IARC) as class 1 human carcinogen [8].

The monohydroxy derivative (AFM1) of AFB1 is produced after metabolization following consumption of contaminated feed by lactating cows. After ingestion of contaminated feed meal, AFM1 is present in cow's milk with the percentage of $1-6 \%$ of AFB1 from a few hours after the ingestion of contaminated meal and up to two days after suspension of the feeding diet [9]. The occurrence and incidence of AFM1 contamination in milk and dairy products varies according to the country of origin [10]. Contamination of milk and dairy products is of public health concern mainly in growing infants because they depend on milk as a major source of nutrients [11]. Strict regulations about the permissible level of AFM1 in milk and dairy products in the developed countries are applied due to the high hepatocarcinogenic potential of the toxin.

More restrictive milk limit for consumption by nursing infants and children are implemented by the European Union (EU) legislation on food contaminants due to the slower rate of carcinogen biotransformation in children than in adults [12] .

A wide variety of methods were applied to control and decrease AFM1 contamination of feed and food. Elimination of aflatoxin with physical and chemical methods have some disadvantages which limit their use such as insufficiency of toxin elimination, high costs and losing the nutritional value of the product [13]. The present study was undertaken to (i) determine the AFM1 level in milk and some dairy products, (ii) compare the positive levels, if any, with the permissible limits by the Egyptian Standard and the European Commissions and finally (iii) evaluate the effect of milk manufacture of some dairy products on AFM1 levels.

\section{Material and Methods}

\section{Collection of samples}

Seventy-five samples comprised of raw milk, pasteurized milk, yoghurt, processed cheese and Domiati cheese (15, each) were collected from different local markets in Sharkia Governorate, Egypt. Samples were transported to the laboratory in an insulating container at $4^{\circ} \mathrm{C}$ as soon as possible for AFM1 analysis.

\section{Preparation of samples}

All samples were prepared using the outlined method in the ELISA kits and according to the official method specified in ELISA System Aflatoxin M1.

Twenty milliliters of each milk sample were centrifuged at $3500 \mathrm{rpm}$ for $10 \mathrm{~min}$. After removing the fatty layer, $100 \mu \mathrm{L}$ of the defatted milk were used for the determination of AFM1. For yoghurt samples, ten grams of each yoghourt sample were added to $100 \mathrm{~mL}$ of warm $\left(20-25^{\circ} \mathrm{C}\right)$ deionized water and shaked for 10 mins in speed of $250 \mathrm{rpm}$ for 1 min. Centrifugation was carried out at 3500 rpm for 10 mins at $4^{\circ} \mathrm{C}$. Following discarding the upper creamy layer, the lower phases were further diluted 20 times (v/v) with deionized water and $100 \mu \mathrm{L}$ of the diluted samples were used for AFM1 estimation.

From each cheese sample, $2 \mathrm{~g}$ were homogenized and added to $40 \mathrm{~mL}$ of dichloromethane. Extraction of the mixture was carried out by shaking for $15 \mathrm{~min}$, and then the suspensions were filtered and $10 \mathrm{~mL}$ of the filtrate were evaporated at $60^{\circ} \mathrm{C}$ under weak $\mathrm{N}_{2}$ stream. The oily residue was redissolved in a mixture of $0.5 \mathrm{~mL}$ phosphate buffer saline, $0.5 \mathrm{~mL}$ methanol and $1 \mathrm{~mL}$ of heptane. Centrifugation of the mixture was performed at $2700 \mathrm{rpm}$ for $15 \mathrm{~min}$. Afetr removing the upper layer of heptane, $100 \mu \mathrm{L}$ of the aliquot were diluted with $400 \mu \mathrm{L}$ of kit buffer and $100 \mu \mathrm{L}$ of the diluted samples were used for AFM1 determination.

\section{Quantitative analysis of AFM1 by competitive ELISA}

Competitive ELISA (RIDASCREEN AFM1, R-Biopharm) procedure as described by in the manufacturer guidelines was used for the quantification of AFM1 in milk and dairy products.

\section{The effect of manufacture on AFM1 level}

Yoghurt manufacture and storage 
Three naturally contaminated milk samples with AFM1 concentration of 35,55 and 70 $\mathrm{ng} / \mathrm{L}$ were used in the experiment. Two hundred $\mathrm{mL}$ of each sample were heated in water bath at $92^{\circ} \mathrm{C}$ for $3 \mathrm{~min}$ then cooled to $42^{\circ} \mathrm{C}$ and the starter culture (1\%, v/v) was added [14]. The samples were thoroughly mixed and incubated at $37^{\circ} \mathrm{C}$ till curdling. The incubated yoghurt samples were analyzed at zero time then after 1, 2, 3, 7 and 14 days from storage at refrigeration temperature. At each storage time, three yoghurt samples were used to determine AFM1 level. The $\mathrm{pH}$ was measured at the time of testing throughout the duration of experiment (14 days) by direct insertion of the electrode ( $\mathrm{pH}$ meter, Adwa kft, AD11, Romania) into well mixed samples.

\section{Soft cheese manufacture}

Three naturally contaminated milk samples with AFM1 concentration of 35, 55 and 70 $\mathrm{ng} / \mathrm{L}$ were used for cheese manufacture. From each sample, $750 \mathrm{~mL}$ were heated in water bath at $92^{\circ} \mathrm{C}$ for $3 \mathrm{~min}$ then cooled to $42^{\circ} \mathrm{C}$ then rennet $(3 \mathrm{~mL})$ was added [15]. Following stirring of the samples, they were covered and maintained at $35^{\circ} \mathrm{C}$ for $1 \mathrm{~h}$. The cheese curd was then cut into cubes and the excess whey was removed by squeezing. In small container with air openings, the curd was kept undisturbed for $5 \mathrm{~h}$. Analysis of the curds and whey was carried out in triplicate for AFM1 quantification.

\section{Data Analysis}

A two-way ANOVA using SPSS ver. 22 (IBM Corp., Armonk, NY, USA) was used for all analysis. Results with $\mathrm{P}<0.05$ were considered significantly different.

Table 1: Levels of Aflatoxin M1 in examined milk and dairy products samples

\begin{tabular}{lcccc}
\hline Sample & No. of samples & No. of positive samples (\%) & Range (ng/ L or Kg) & Mean \pm SE \\
\hline Milk & 15 & $5(33.3)$ & $6.40-70$ & $35.68 \pm 10.90$ \\
Pasteurized milk & 15 & $6(40)$ & $25.60-73.60$ & $45.83 \pm 7.80$ \\
Yoghurt & 15 & $3(20)$ & $3.30-11.40$ & $7.57 \pm 1.92$ \\
Processed cheese & 15 & $6(40)$ & $12.50-38.70$ & $24.53 \pm 3.91$ \\
Domiati cheese & 15 & $7(46.7)$ & $22.60-74.23$ & $47.68 \pm 6.94$ \\
\hline
\end{tabular}

\section{Results and Discussion}

In the current study, a total of 75 milk and dairy products' samples were analyzed for AFM1. The results revealed that 27 (36\%) out of the examined samples were contaminated with AFM1. The occurrence of AFM1 in raw milk samples ranged from 6.40 to $70 \mathrm{ng} / \mathrm{L}$ with a mean value of $35.68 \pm 10.90$. Of these samples, 5 (33.3\%) exceeded the Egyptian regulation limit for AFM1 (0 ng/L) while only $2(13.3 \%)$ samples exceeded the European Commission regulation $(50 \mathrm{ng} / \mathrm{L})$ (Table 2). Lower findings were obtained by Aiad and Aboelmakarem [16] while higher result by Hosny et al. [17]. The present study revealed the contamination of the examined samples with AFM1 in milk and dairy products thus posing a potential risk to human health.

Table 2: levels of Aflatoxin M1 in examined samples in comparison to levels of the existing regulations.

\begin{tabular}{lccc}
\hline Sample & $\begin{array}{c}\text { Positive } \\
\text { samples }\end{array}$ & $\begin{array}{c}\text { Exceeding Egyptian Regulation } \\
\text { (free from AFM1) }\end{array}$ & $\begin{array}{c}\text { Exceeding EC Regulations } \\
\text { (50 ng/Kg) }\end{array}$ \\
\hline Raw milk & 5 & 5 & 2 \\
Pasteurized milk & 6 & 6 & 2 \\
Yoghurt & 3 & 3 & 0 \\
Processed cheese & 6 & 6 & 0 \\
Domiati cheese & 7 & 7 & 2 \\
\hline
\end{tabular}

EC: European Commission regulation 
For pasteurized milk samples, $6(40 \%)$ out of the examined samples were contaminated with AFM1 with a value ranged from 25.60 $73.60 \mathrm{ng} / \mathrm{L}$ and a mean value of $45.83 \pm 7.80$. All positive samples exceeded the Egyptian regulation limit for AFM1, while, only 2 $(13.3 \%)$ samples exceeded the European Commission regulation.(Tables 1, 2). Higher values were detected by Hosny et al. [17] and Çelik et al. [18].

The contamination level of the yoghurt samples ranged from 3.30 to $11.40 \mathrm{ng} / \mathrm{kg}$, with 3 (20\%) samples exceeded the Egyptian regulation limit for AFM1, while, no samples exceeded the European Commission regulation. Concerning the results of processed cheese samples, AFM1 was detected in 6 (40\%) samples with a contamination level ranged from $12.50-38.70 \mathrm{ng} / \mathrm{kg}$ with a mean value of $24.53 \pm 3.91$. All the positive samples exceeded the Egyption regulation limit, while no samples exceeding the European Commission regulation (Tables 1, 2).

According to Elsayed and Abdelfatah [19] and Temamogullari and Kanici [20], AFM1 was detected in both yoghurt and processed cheese samples in lower percentage, while Iqbal and Asi [21] detected the toxin in both products with higher percentage than our results.

Table 3: Concentrations of Aflatoxin M1 (ng/L or $\mathrm{kg}$ ) after manufacturing of yoghurt at different intervals $(*$ Means $\pm \mathrm{SE})$

\begin{tabular}{|c|c|c|c|c|c|c|}
\hline \multirow[t]{2}{*}{ time } & \multicolumn{3}{|c|}{ Yoghurt } & \multicolumn{3}{|c|}{ pH } \\
\hline & $\begin{array}{c}\text { Trial } 1 \\
(35 \text { ng/L) }\end{array}$ & $\begin{array}{c}\text { Trial } 2 \\
(55 \mathrm{ng} / \mathrm{L})\end{array}$ & $\begin{array}{c}\text { Trial } 3 \\
(70 \mathrm{ng} / \mathrm{L})\end{array}$ & Trial 1 & Trial 2 & Trial 3 \\
\hline $\begin{array}{l}\text { Pasteurized } \\
\text { milk }\end{array}$ & $34.67 \pm 0.05^{\mathrm{a}}$ & $54.57 \pm 0.15^{a}$ & $65.13 \pm 0.07^{\mathrm{a}}$ & $6.59 \pm 0.00^{a}$ & $6.63 \pm 0.01^{a}$ & $6.56 \pm 0.02^{a}$ \\
\hline Zero time & $31.17 \pm 0.09^{b}$ & $52.23 \pm 0.15^{\mathrm{b}}$ & $58.17 \pm 0.10^{\mathrm{a}}$ & $6.43 \pm 0.02^{a}$ & $6.42 \pm 0.06^{b}$ & $6.45 \pm 0.05^{a}$ \\
\hline 1 day & $30.40 \pm 0.17^{\mathrm{c}}$ & $46.60 \pm 0.12^{c}$ & $52.47 \pm 0.15^{\mathrm{c}}$ & $4.73 \pm 0.10^{\mathrm{b}}$ & $4.75 \pm 0.07^{c}$ & $4.63 \pm 0.01^{b}$ \\
\hline 2 days & $19.43 \pm 0.19^{\mathrm{d}}$ & $44.57 \pm 0.15^{\mathrm{d}}$ & $47.57 \pm 0.23^{\mathrm{d}}$ & $4.55 \pm 0.05^{b}$ & $4.55 \pm 0.05^{c}$ & $4.57 \pm 0.05^{\mathrm{c}}$ \\
\hline 3 days & $18.33 \pm 0.17^{\mathrm{d}}$ & $44.10 \pm 0.05^{\mathrm{e}}$ & $42.40 \pm 0.12^{\mathrm{e}}$ & $4.50 \pm 0.10^{c}$ & $4.54 \pm 0.00^{c}$ & $4.49 \pm 0.02^{\mathrm{d}}$ \\
\hline 7 days & $15.53 \pm 0.22^{\mathrm{d}}$ & $43.73 \pm 0.07^{\mathrm{f}}$ & $41.83 \pm 0.10^{\mathrm{g}}$ & $4.42 \pm 0.03^{\mathrm{d}}$ & $4.34 \pm 0.06^{\mathrm{d}}$ & $4.42 \pm 0.06^{\mathrm{d}}$ \\
\hline 14 days & $15.57 \pm 0.23^{\mathrm{d}}$ & $43.83 \pm 0.03^{\mathrm{f}}$ & $41.83 \pm 0.10^{\mathrm{g}}$ & $4.06 \pm 0.05^{\mathrm{e}}$ & $4.00 \pm 0.01^{\mathrm{d}}$ & $4.11 \pm 0.03^{\mathrm{e}}$ \\
\hline
\end{tabular}

Means with different superscript letters (within a parameter) are significantly different $(\mathrm{P}<0.05)$.

*Mean of three samples analysed

Regarding Domiati cheese, $46.7 \%$ of the samples were contaminated with AFM1 with levels ranged between $22.60-74.23 \mathrm{ng} / \mathrm{kg}$ and a mean value of $47.68 \pm 6.94$. All the positive samples exceeded the Egyption regulation limit, while, $2(13.3 \%)$ samples exceeded the European Commission regulation (Tables 1, $2)$. Higher result was reported by Hosny et al. [17]. In another investigations, AFM1 was detected in cheese with the values $64,64.8,78$ and $80 \%$ [22-25].

In our study, the results clarified that yoghurt was the lowest in the contamination level among all the examined products, while, cheese samples have the highest contamination level.

The detection levels of AFM1 during fermentation and storage at refrigeration are shown in Table 3. Milk contaminated with AFM1 in three concentrations; 35, 55 and 70
ng/L were used for the experiment. The mean concentrations of the toxin in yoghurt for the three concentrations respectively, decreased with the percentages of $0.9,10.9,13.1,44.5$, 47.6, 55.6; 0. 8, 5, 15.3, 19, 19.8, 20.5 and 7 , $16.9,25,32,39.4,40.2$ in pasteurized milk then at zero time (fresh yoghurt), and after one, two, three, seven days, respectively, then nearly similar level of AFM1 from seven days to fourteen days of storage. The decreases in AFM1 levels were associated with a gradual decrease in $\mathrm{pH}$ values. Statistical significant differences $(\mathrm{P}<0.05)$ between the decrease in concentrations of AFM1 were detected after yoghurt manufacturing. The significant reduction of AFM1 with yoghurt manufacturing is in agreement with Govaris et al. [14]; Aiad and Aboelmakarem [16] and Iha et al. [26]. In contrary, Bakirci [27] detected variable AFM1 content increase $(13 \%)$ in yoghurt related to the milk contamination. 
Other studies reported no influence on AFM1 content upon manufacturing of yoghurt or storage for 7 days at $7^{\circ} \mathrm{C}[28,29]$. Several factors including low $\mathrm{pH}$, formation of organic acids or other byproducts fermentation and even to the presence of Lactobacillus species could be contributed to the decrease in AFM1 level. Moreover, changes in milk protein structure such as formation of yoghurt coagulum from casein are resulted from the decrease in $\mathrm{pH}$ during fermentations [30]. This structure change affecting the AFM1 association with this protein [31] leading to adsorption or occlusion of the toxin in the precipitate. Lactic acid bacteria (LAB) such as Lactobacillus bulgaricus and Streptococcus thermophilus have the ability to bind with AFM1 [32], thus, resulting in the reduction of free AFM1 content in liquid culture medium and during yogurt processing. Consequently, LAB can be used for reduction of AFM1 as a biological agent.

Table 4: Concentration of Aflatoxin M1 (AFM1) during soft cheese manufactured during this study

\begin{tabular}{|c|c|c|c|c|c|}
\hline \multirow[t]{2}{*}{ Trials } & \multirow[t]{2}{*}{ Samples } & \multirow[t]{2}{*}{ Amounts (mL or g) } & \multicolumn{3}{|c|}{ AFM1 } \\
\hline & & & $(\mathbf{n g} / \mathbf{L}, \mathbf{k g}) *$ & Total mass (ng) & $\begin{array}{l}\% \text { of Total } \\
\text { AFM1 mass }\end{array}$ \\
\hline \multirow[t]{4}{*}{1} & Milk & 750 & 35 & 26.25 & 100 \\
\hline & Whey & 700 & $14.29 \pm 0.02$ & 10 & 38.1 \\
\hline & Cheese & 123.1 & $73.11 \pm 0.04$ & 9 & 34.3 \\
\hline & Decrease & & & 7.25 & 27.6 \\
\hline \multirow[t]{4}{*}{2} & Milk & 750 & 55 & 41.25 & 100 \\
\hline & Whey & 730 & $22.77 \pm 0.07$ & 16.62 & 40.3 \\
\hline & Cheese & 129.6 & $102.78 \pm 0.00$ & 13.32 & 32.3 \\
\hline & Decrease & & & 10.08 & 27.4 \\
\hline \multirow[t]{4}{*}{3} & Milk & 750 & 70 & 52.5 & 100 \\
\hline & Whey & 725 & $28.34 \pm 0.03$ & 20.55 & 39.2 \\
\hline & Cheese & 132.7 & $123.51 \pm 0.04$ & 16.39 & 31.2 \\
\hline & Decrease & & & 15.56 & 29.6 \\
\hline \multirow[t]{4}{*}{ Means } & Milk & 750 & $53.33 \pm 8.28$ & 40 & 100 \\
\hline & Whey & 718.33 & $21.8 \pm 9.21$ & 15.72 & 39.2 \\
\hline & Cheese & 128.47 & $99.8 \pm 8.30$ & 12.90 & 32.6 \\
\hline & Decrease & & & 10.96 & 28.2 \\
\hline
\end{tabular}

*Mean of three samples analysed.

During soft cheese production, AFM1 distribution in curd and whey is illustrated in Table 4. The total AFM1 content decreased by 27.6, 27.4 and $29.6 \%$ in the three trials. This reduction could be attributed to several factors such as, the interaction between the toxin and the protein in the products, the use of cheese cloth and production environment. In the curds, the concentrations of AFM1 over three trials were 2.08, 1.87 and 1.76-fold higher than in cheese milk, this was consistent with the findings previously reported $[16,26]$. However, an increase of 2 and 4-folds was previously reported [27, 33-35]. The relatively higher content of water (residual whey) in the samples might have contributed to such difference. The mean of AFM1 concentration in whey $(39.2 \%)$ was inagreement with Bakirci [27], while, other studies reported arange of 40 to $60 \%$ [33-35].
Variable AFM1 contamination levels in different types of cheese samples have been reported in several studies. This could be attributed to different factors such as procedures of cheese manufacturing and storage conditions including humidity and temperature which are essential for toxin production [36]. In addition, extraction technique, methodology, type and degree of milk contamination, differences in milk quality and the presence of curd in whey could influence AFM1 concentration during cheese manufacturing process [16]. Cheese types, conditions of cheese ripening [35] and the seasonal and geographical effects are factors that have also influence in the level of AFM1 [37]. Association of AFM1 with casein fraction in milk, have contributed to consider 
cheese as the most important source of aflatoxin [38].

Aflatoxicosis is the disease resulted from presence of aflatoxins in humans. Therefore, the presence of AFM1 may be specified as Aflatoxicosis M1. Consequently, AFM1 is considered as an etiological factor for a foodborne zoonosis namely Aflatoxicosis M1 [39]. The most prominent signs of aflatoxicosis include hemorrhage, anemia, reduction of immune function, hepatotoxicosis, teratogenesis, carcinogenesis and mutagenesis. The target organ for the carcinogenic and toxic effect of AFs is liver [40]. Increased risk of developing cancer in humans has been linked to the exposure to AFM1 [41], thus WHO-IARC [42] changed its classification from group 2 (possibly human carcinogen) to group 1 (human carcinogen) agents. The level and duration of exposure to AFM1 have influenced its carcinogenicity. Regular consumption of milk and dairy products (infant milk, yoghurt, cheese, butter) is the main routes of exposure to the toxin [43]. Therefore, strict regulations about the AFM1 maximum permissible limit in milk and dairy products have been issued by several countries to protect consumers especially children [44].

\section{Conclusion}

In conclusion, this study revealed that AFM1 could be found in dairy products manufactured from contaminated milk, therefore, the only practical way to ensure the safety of milk and dairy products for human consumption is avoiding their contamination. Yoghurt manufacture resulted in a decrease in the AFM1 contents while cheese manufacture from AFM1 contaminated milk showed concentration of AFM1 in curd than those in cheese milk. Using new or modern technologies for detoxification of milk should be further studied. Applying of a food control system, such as the HACCP system, in the food industries is suggested as an efficient means for limiting contamination of mycotoxin.

\section{Conflict of interest}

None of the authors have any conflict of interest.

\section{References}

[1] Galvano, F.; Galofaro, V.; DeAngelis, A.; Galvano, M.; Bognanno, M. and Galvano, G. (1998): Survey of the occurrence of aflatoxin M1 in dairy products marketed in Italy. J Food Protection, 61(6): 738-741.

[2] Colak, H. (2007): Determination of aflatoxin M1 levels in Turkish white and kashar cheeses produced from experimentally contaminated raw milk. J. Food and Drug Anal. 15(2): 163- 168.

[3] Iqbal, S.Z.; Asi, M.R. and Ariño, A. (2011): Aflatoxin M1contamination in cow and buffalo milk samples from the North West Frontier Province (NWFP) and Punjab provinces of Pakistan. Food Addit Contam: Part B, 4(4): 282-288.

[4] Bryden, W.L. (2012): Mycotoxin contamination of the feed supply chain: implications for animal productivity and feed security. Anim Feed Sci Technol, 173(1): 134-158.

[5] Castegnaro, M. and McGregor, D. (1998): Carcinogenic risk assessment of mycotoxins. Rev MedVet, 149(6): 671678.

[6] Asi, M.R., Iqbal, S.Z.; Ariño A. and Hussain, A. (2012): Effect of seasonal variations and lactation times on aflatoxin M1contamination in milk of different species from Punjab, Pakistan. Food Control, 25(1): 34-38.

[7] Dohnal, V.; Wu, Q. and Kuca, K. (2014): Metabolism of aflatoxins: Key enzymes and interindividual as well as interspecies differences. Arch Toxicol, 88(9):1635-1644.

[8] IARC (International Agency for Research on Cancer) (1993): Some naturally occurring substances: Food items and constituents, heterocyclic aromatic amines and mycotoxins. IARC Monograph on the Evaluation of Carcinogenic Risks to Humans, World Health Organization, Lyon, France, 56: $1-391$.

[9] Gürbay, A.; Aydin, S.; Girgin, G.; Engin, A.B. and Sahin, G.( 2006): Assessment of aflatoxin M1 levels in milk in Ankara, Turkey. Food Control, 17(1):1-4.

[10] Prandini, A.; Tansini, G.; Sigolo, S.; Filippi, L.; Laporta, M., and Piva, G. 
(2009): On occurrence of aflatoxin M1 in milk and dairy products. Food Chem Toxicol, 47(5): 984-991.

[11] Elkak, A.; El Atat, O.; Habib J. and Abbas, M. (2012): Occurrence of a flatoxin M1 in cheese processed and marketed in Lebanon. Food Control, 25(1): 140-143.

[12] The Commission of the European Communities (2006): Commission Regulation (EC) No 1881/2006 of 19 December 2006. Setting maximum levels for certain contaminants in foodstuffs. Off J Eur Union, L 364, 1-24.

[13] Line, J. E. and Brackett, R. E. (1995): Factors Affecting Aflatoxin B1 Removal by Flavobacteriumaurantiacum. J Food Prot, 58(1): 91-94.

[14] Govaris, A.; Roussi, V.; Koidis, P. A. and Botsoglou N. A. (2002): Distribution and stability of aflatoxin M1 during production and storage of yoghurt. Food Addit Contam, 19(11): 1043-1050.

[15] El-Gawad, M.A.M.A. (2009): Enhancement of white soft cheese ripening made from buffalo's milk retentate through addition of commercial preparation of yeast extract. Egypt J Dairy Sci, 37(1) :65-72.

[16] Aiad, A.S. and Aboelmakarem, H.S. (2013): Aflatoxin M1levels in milk and some dairy products in Alexandria city. Assiut Vet Med J, 59 (139): 94-98.

[17] Hosny, G.; El-sadany, M.A. and Atwa, M.A. (2014): Monitoring of aflatoxin M1 in some dairy products in local market of Alexandria, Egypt : Attempts for detoxification. Int Res $\mathrm{J}$ Sci Findings, 1: 53-64.

[18] Çelik, T.A.; Sarımehmetoğlu, B. and Küplülü, O. (2005): Aflatoxin M1 contamination in pasteurised milk. Vet Arhiv 75(1): 57- 65.

[19] Elsayed, M.S. and Abd El-Fatah, E.N. (2015): Prevalence of aflatoxin M1 in some milk products widely consumed by infants and children, marketed in Sharkia, Egypt. Global Vet, 14(4): 560566.

[20] Temamogullari, F. and Kanici, A. (2014): Short communication: Aflatoxin M1 in dairy products sold in anliurfa, Turkey. J Dairy Sci, 97(1): 162-165.
[21] Iqbal, S.Z. and Asi, M.R. (2013): Assessment of aflatoxin M1in milk and milk products from Punjab, Pakistan. Food Control, 30(1):235-239.

[22] Tavakoli, H.R.; Riazipour, M.; Kamkar, A.; Shaldehi, H.R. and Nejad, A.S.M. (2012): Occurrence of aflatoxin M1in white cheese samples from Tehran, Iran. Food Control, 23(1): 293-295.

[23] Duarte, S.C.; Almeida, A.M.; Teixeira, A.S.; Pereira, A.L.; Falcão, A.C.; Pena A. and Lino, C.M. (2013): Aflatoxin M1in marketed milk in Portugal: Assessment of human and animal Exposure. Food Control, 30(2): 411-417.

[24] Elkak, A.; El Atat, O.; Habib, J. and Abbas, M. (2012): Occurrence of a flatoxin $\mathrm{M} 1$ in cheeseprocessed and marketed in Lebanon. Food Control, 25(1): 140-143.

[25] Mohajeri, F.A.; Ghalebi, S.A.; Rezaeian, M.; Gheisari, H.R.; Azad, H.K.; Zolfaghari, A.; Aziz A. and Fallah, A. (2013): aflatoxin M1contamination in white and Lighvan cheese marketed in Rafsanjan, Iran. Food Control, 33(2): 525-527.

[26] Iha, M.H.; Barbosa, C.B.; Okada, I.A. and Trucksess, M.W. (2013): Aflatoxin M1 in milk and distribution and stability of aflatoxin M1 duringproduction and storage of yoghurt and cheese. Food Control, 29(1):1-6.

[27] Bakirci, I. (2001): A study on the occurrence of aflatoxin M1 in milk and milk products produced in Van province of Turkey. Food Control, 12(1): 47-51.

[28] El Deeb, S. A.; Zaki, N.; Shoukry, Y.M.R. and Kheadr, E.E. (1992): Effect of some technological processes on stability and distribution of aflatoxin M1 in milk. Egypt J Food Sci, 20: 29-42.

[29] Blanco, J.L.; Carrion, B.A.; Liria, N.; Diaz, S.; Garcia, M. E.; Domingues, L.and Suarez, G. (1993): Behavior of aflatoxin during manufacture and storage yogurt. Milchwissenchaft, 48: 385-387.

[30] Govaris, A.; Roussi,V.; Koidis, A. and Botsoglou, N.A. (2001): Distribution and stability ofaflatoxin M1 during processing, ripening and storageof Telemes cheese. Food Addit Contam, 18(5): 437-443. 
[31] Brackett, R.E. and Marth, E.H. (1982): Association of aflatoxin M1 with casein. Zeitschrift LebensmittelUntersuchung Forschung, 174(6): 439-441.

[32] El Khoury, A.; Atoui, A. and Yaghi, J. (2011): Analysis ofaflatoxin M1 in milk and yogurt and AFM1 reduction by lactic acid bacteria used in Lebanese industry. Food Control, 22(10): 1695-1699.

[33] Manetta, A. C.; Giammarco, M.; Giuseppe, L.D.; Fusaro, I.; Gramenzi, A.; Formigoni, A.;Vignola, G. and Lambertini, L. (2009): Distribution of aflatoxin M1 during Grana Padano cheeseproduction from naturally contaminated milk. Food Chemi, 113(2): 595-599.

[34] Oruc, H. H.; Cibik, R.; Yikmaz, E. and Gunes, E. (2007): Fate of aflatoxin M1 in kasharcheese. J Food Saf, 27(1): 8290.

[35]Oruc, H. H.; Cibik, R.;Yikmaz, E. and Kalkanli, O. (2006): Distribution and stability ofaflatoxin M1 during processing and ripening of traditional white pickledcheese. Food AdditContam, 23(2): 190-195.

[36] Deveci, O. (2007): Changes in the concentration of aflatoxin M1 during manufacture and storage of white pickled cheese. Food Control, 18(9): 1103-1107.

[37] Tajkarimi, M.; Aliabadi-Sh, F.; Nejad, A. S.; Pursoltani, H.; Motallebi, A.A. and Mahdavi, H. (2008): A flatoxin M1 contamination in winter and summermilk in 14 states in Iran. Food Control, 19(11): 1033-1036.

[38] Yapar, K.; Elmali, M.; Kart, A. and Yaman, H. (2008): Aflatoxin M1 levels in different types of cheese products produced in Turkey. MedycynaWeterynaryjna, 64(1): 53-55.

[39] El-Tras, W.F.; El-Kady, N.N. and Tayel, A.A. (2011): Infants exposure to aflatoxin $\mathrm{M}_{1}$ as a novel foodborne zoonosis. Food Chem Toxicol, 49: 28162819.

[40] Buldu, H.M.; Koc, A.N. and Uraz, G. (2011): Aflatoxin M1 contamination in Cow's milk in Kayseri (Centralof Turkey). Turk J Vet Anim Sci, 35(2): 15.

[41] Wogan, G.N.; Hecht, S.S.; Felton, J.S. ; Conney, A.H. and Loeb, L.A. (2004): Environmental and chemical carcinogenesis. Seminars in Cancer Biology, 14(6): 473-486.

[42] WHO-International Agency for Research on Cancer (IARC), (2002): Monograph on the evaluation ofcarcinogenic risks to humans. WHO, 82: 171-275.

[43] Caloni, F.; Stammati, A.; Friggè, G. and Angelis, I. D. (2006): Aflatoxin M1 absorption and cytotoxicity onhuman intestinal in vitro model. Toxicon, 47(4): 409-415.

[44] Elkak, A.; El Atat, O.; Habib, J. and Abbas, M. (2012): Occurrence of aflatoxin M1 in cheeseprocessed and marketed in Lebanon. Food Control, 25(1): 140-143. 


\section{الملخص العربي}

\section{الأقلاتوكسين M1 في الحليب وبعض منتجات الألبان : مستواه وتأثير التصنيع و المخاطر الصحية العامة المتعلقة به}

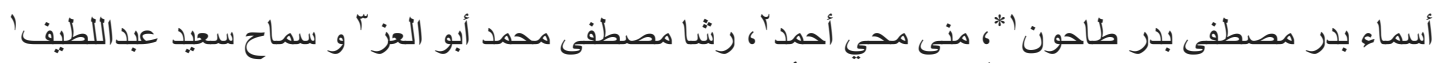

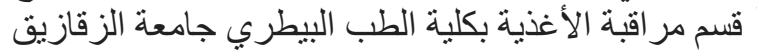

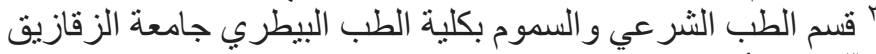

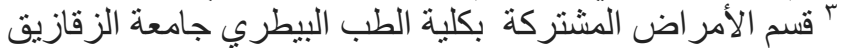

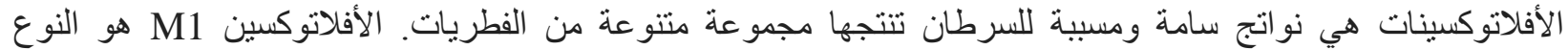

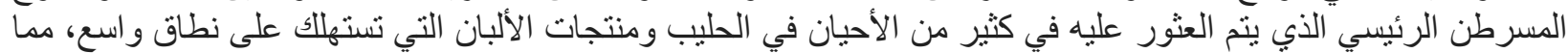

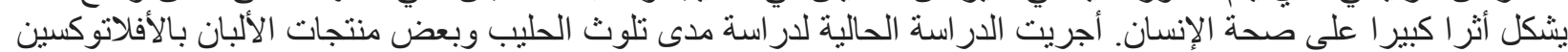

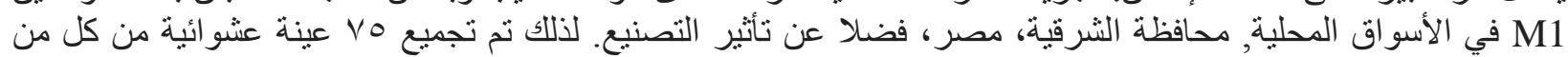

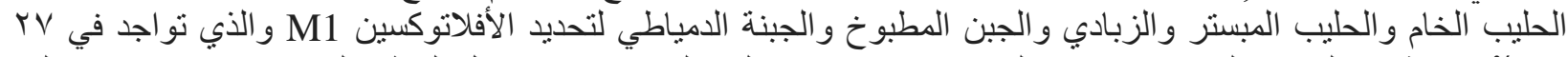

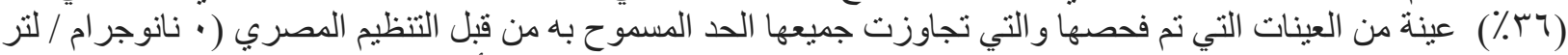

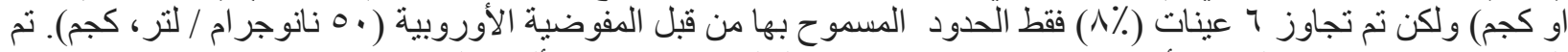

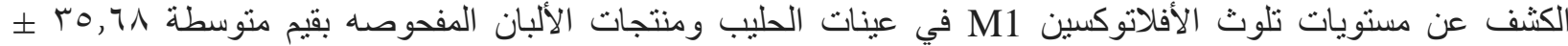
.

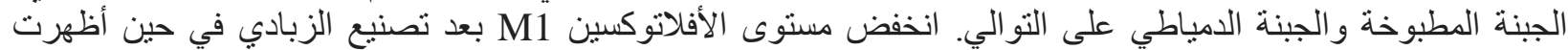

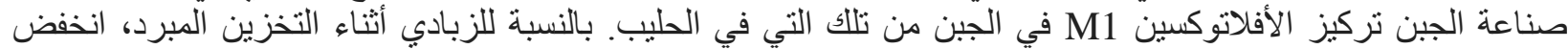

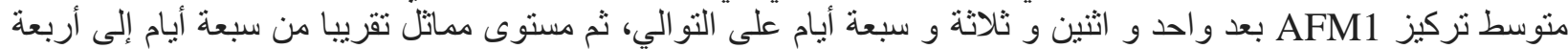

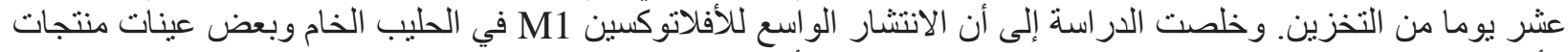

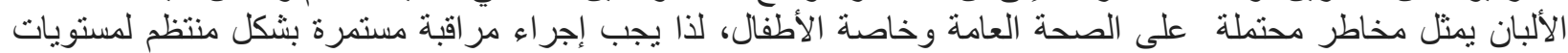

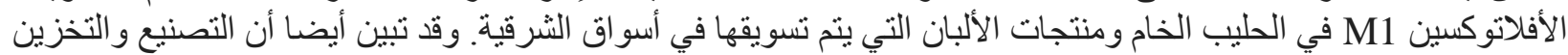

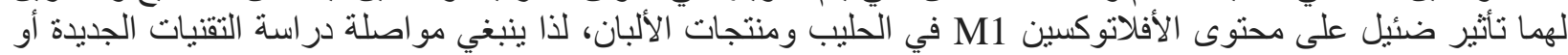
الحديثة لإز الة السموم من الحليب. 